Supplement of Solid Earth, 10, 1-14, 2019 https://doi.org/10.5194/se-10-1-2019-supplement (C) Author(s) 2019. This work is distributed under the Creative Commons Attribution 4.0 License.

(c) (1)

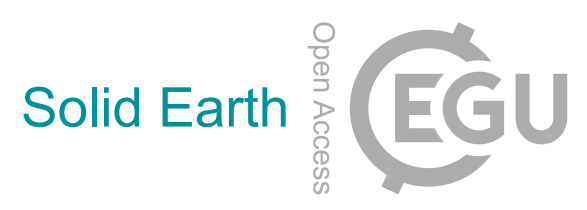

Supplement of

\title{
High-precision U-Pb ages in the early Tithonian to early Berriasian and implications for the numerical age of the Jurassic-Cretaceous boundary
}

Luis Lena et al.

Correspondence to: Luis Lena (lena.luis@gmail.com, luis.fortesdelena@unige.ch)

The copyright of individual parts of the supplement might differ from the CC BY 4.0 License. 


\section{Sample preparation}

Ash beds were crushed using a tungsten mill. The crushed samples were then sieved at $300 \mu \mathrm{m}$. A water flotation method was used to separate and remove the very fine grain size material (less than 20 microns), resulting in a fine material with mineral grains ranging from 20 to $300 \mu \mathrm{m}$. The material was then separated with a magnetic separator at a current of $1.8 \mathrm{~A}$ using a Frantz unit. The non-magnetic material was then run through heavy liquid density separation method using Methyl Iodide from Geoliquids Inc. Minerals denser than $3.33 \mathrm{~g} / \mathrm{cm}^{3}$ sank and collected, were zircons were expected to be found. Single grains zircons were then hand-picked using a transmitted light microscope.

\section{Laboratorial procedures}

Ten to twenty grains were selected for annealed at $900^{\circ} \mathrm{C}$ for 48 hours. Grains from each sample were then separately chemically abraded, in bulk, for 12 hours in $3 \mathrm{ml}$ Teflon beakers at $210^{\circ} \mathrm{C}$ with $12 \mathrm{~N} \mathrm{HF}$ inside a pressure dissolution vessel. Following chemical abrasion, the grains were then individually placed inside $3 \mathrm{ml}$ Teflon beakers rinsed and cleaned. The cleaning of grains consisted of several steps. In the first step, grains are left for 12 hours (overnight) in $6.2 \mathrm{~N} \mathrm{HCl}$ inside $3 \mathrm{ml}$ Savilex beaker at $80^{\circ} \mathrm{C}$ on a hot plate. In the second step, the grains were cleaned using $7 \mathrm{~N} \mathrm{HNO}_{3}$, which consisted of a $45 \mathrm{~min}$ hot bath on a sonicator with and an additional $60 \mathrm{~min}$ hot bath on hotplate at $80^{\circ} \mathrm{C}$. The $7 \mathrm{~N} \mathrm{HNO}_{3}$ was then removed from the beakers and the process repeated three times before moving to total dissolution of the grains. Total dissolution consisted of grains being placed individually in microcapsules in $12 \mathrm{~N} \mathrm{HF}$ for 48 hours at $210^{\circ} \mathrm{C}$. After total dissolution, microcapsules were then placed on a hotplate at $120^{\circ} \mathrm{C}$ uncapped to evaporate the remaining $\mathrm{HF}$ remaining from the total dissolution. Subsequently, $6.2 \mathrm{~N} \mathrm{HCl}$ was added to the microcapsules and put back in the oven for 12 hours at $180^{\circ} \mathrm{C}$ for total conversion. After the conversion of acids, the microcapsules were then placed on a hot at $80^{\circ} \mathrm{C}$ to evaporate the $6.2 \mathrm{~N} \mathrm{HCl}$ remaining from conversion. After evaporation, $3.1 \mathrm{~N} \mathrm{HCl}$ was added to the microcapsules before eluting $\mathrm{Pb}$ and $U$ using micro columns. The micro columns were first cleaned using four steps alternating $6.2 \mathrm{~N} \mathrm{HCl}$ and ultrapure $\mathrm{H}_{2} \mathrm{O}$. Samples were collected in $7 \mathrm{ml}$ savillex beakers. Cleaning of $7 \mathrm{ml}$ beakers are done in a three-step process of $12 \mathrm{~h}$ in $6.2 \mathrm{~N} \mathrm{HCl}, 12 \mathrm{~h}$ in $12 \mathrm{~N}$ $\mathrm{HF}$, and $12 \mathrm{~h}$ of $6.2 \mathrm{~N} \mathrm{HCl}$ on the hotplate at $80^{\circ} \mathrm{C}$. General chemical abrasion procedures are followed after Mattinson (2005). 


\section{Data acquisition}

After the full laboratorial procedures, the samples were dissolved into a silica gel and gently placed on outgassed Re filaments. Isotopic ratios were acquired using Thermal Ionization Mass Spectrometry. Samples were run using a either the Thermo Finnigan TRITON or Isotopx Phoenix in the Department of Earth Sciences, University of Geneva, Switzerland. Lead $(\mathrm{Pb})$ measurements were acquired in dynamic mode on the SEM (Triton) or the Daly (Pheonix). Auto focusing and Peak centering were performed at the beginning of each block, which consisted of 20 cycles each. Lead baseline was monitored by mass 203.5. Interferences on mass ${ }^{202} \mathrm{~Pb}$ and ${ }^{205} \mathrm{~Pb}$ were monitored by masses 201 and 203 , respectively. EARTHTIME ${ }^{202} \mathrm{~Pb}_{-}{ }^{205} \mathrm{~Pb}_{-}{ }^{235} \mathrm{U}_{-}{ }^{233} \mathrm{U}$ and EARTHTIME ${ }^{205} \mathrm{~Pb}_{-}{ }^{235} \mathrm{U}_{-}{ }^{233} \mathrm{U}$ were used as spikes (Parrish et al., 2006; Parrish and Krogh, 1987). Each measured ratio was corrected for fractionation using a ${ }^{202} \mathrm{~Pb} /{ }^{205} \mathrm{~Pb}$ of 0.99989 when the ${ }^{202} \mathrm{~Pb}^{205} \mathrm{~Pb}^{235} \mathrm{U}-{ }^{233} \mathrm{U}$ and EARTHTIME was used. When EARTHTIME ${ }^{205} \mathrm{~Pb}_{-}-{ }^{235} \mathrm{U}_{-}^{233} \mathrm{U}$ was used $\mathrm{Pb}$ fractionation was assumed to be $0.13 \pm 0.5 \%$ a.m.u (2 S.D). All common $\mathrm{Pb}$ measured was assumed to be from laboratorial blanks. Any sample that contained over $1 \mathrm{pg}$ of common $\mathrm{Pb}$ was considered to be contaminated and discarded.

Uranium measurements were made in static mode on Faraday cups $10^{12} \Omega$ resistors as $\mathrm{UO}_{2}{ }^{+}$. Auto focusing and peak centering was performed at the beginning of every block, with each block consisting of 20 cycles each. Baselines were monitored on \pm 0.5 mass units. ${ }^{238} \mathrm{U} /{ }^{235} \mathrm{U}$ of the sample and blank was assumed to be 137.88 (Chen and Wasserburg, 1980). The oxide correction in $\mathrm{U}$ measurements was assumed ${ }^{16} \mathrm{OU} /{ }^{18} \mathrm{OU}=0.002$. Uranium decay constant values were used from Jaffey et al. (1971).

Raw U-Pb data was reduced using U-Pb Redux (Bowring et al., 2012) and the data reported in TS.1. Uncertainty and error propagation algorithm used in Redux software is described in McLean et al. (2011). For the initial Th disequilibrium deviation was calculated using ${ }^{208} \mathrm{~Pb}$ and a Th/U of the magma was assumed to be 3.5 (Blackburn et al., 2013).

\section{Ash bed age interpretation}

All zircons considered in the age distribution of the ash are interpreted as ash-fall deposits from near-by volcanic eruptions, even though the exact source cannot be known. Individual zircon grains from each sample were analyzed and subsequently the youngest subset of grains from the age distribution of each sample were selected for the final weighted mean age. Ages reported in Fig. 2 and throughout the text are ${ }^{206} \mathrm{~Pb} /{ }^{238} \mathrm{U}$ weighted mean Th-corrected ages. 
Uncertainties are reported as $\mathrm{X} / \mathrm{Y} / \mathrm{Z} ; \mathrm{X}$ includes analytical uncertainty, $\mathrm{Y}$ includes additional tracer (ET2535) calibration uncertainty, and Z includes additional ${ }^{238} \mathrm{U}$ decay constant uncertainty. The final weighted mean ages are interpreted as a depositional age for the ash beds. Chemical abrasion is assumed to eliminate the effect of $\mathrm{Pb}$ loss in individual grains. Therefore, dispersion of individual grains bigger than the analytical uncertainty in individual grains were assumed to record prolonged residence of zircon in the magmatic systems as well as intramagmatic recycling.

\section{Sample Description}

\subsection{Ash bed LL3}

Ash bed LL3 is located at stratigraphic height $54 \mathrm{~m}$ in the Las Loicas section. Zircon yield was moderate to high ca. $>50$ grains. Zircons crystals ranged from $40-80 \mu \mathrm{m}$ in size. Grains were mainly rounded with aspect ratio of 1:3 with rare prismatic crystals being rare. Radiogenic $\mathrm{Pb}$ ranged from 3 to $10 \mathrm{pg}$ (TS.1). A total of nine grains were selected to represent the age distribution of the sample, with 5 grains being discarded for being too old (> 150 Ma) and considered either inherited grains or prolonged magmatic residence, or magmatic recycling. A total of four younger grains (z23, z25, z26, z32) that overlapped were considered for the final weighted mean age of the ash bed. The final weighted mean age of the ash bed is $139.238 \pm 0.049 / 0.061 / 0.16 \mathrm{Ma}, \mathrm{MSWD}=0.56$

\subsection{Ash bed LL9}

Ash bed LL9 is located in stratigraphic height $41 \mathrm{~m}$ in the Las Loicas section. Zircon yield was moderate to high ca. $>50$ grains. Zircons crystals ranged from $40-80 \mu \mathrm{m}$ in size. Grains were mainly prismatic with aspect ratio of $1: 8$. Radiogenic $\mathrm{Pb}$ ranged from 2.5 to 14 pg (TS.1). A total of eleven grains were selected to represent the age distribution of the sample, with 7 grains being discarded for being too old (> 150 Ma) and considered either inherited grains or prolonged magmatic residence, or magmatic recycling. A total of four younger grains $(z 2, z 12, z 51, z 55)$ that overlapped were considered for the final weighted mean age of the ash bed of $139.956 \pm 0.063 / 0.072 / 0.17 \mathrm{Ma}$, MSDW 0.34

\subsection{Ash bed LL10}

Ash bed LL10 is located in stratigraphic height $31 \mathrm{~m}$ in the Las Loicas section. Zircon yield was moderate to high ca. > 50 grains. Zircons crystals ranged from 40-80 $\mu \mathrm{m}$ in size. 
Grains were mainly prismatic with aspect ratio of 1:8. Radiogenic $\mathrm{Pb}$ ranged from 1 to $6 \mathrm{pg}$ (TS.1), notably lower than other the other samples. A total of eight grains were selected to represent the age distribution of the sample, with 4 grains being discarded for being too old $(>\sim 150 \mathrm{Ma})$ and considered either inherited grains or prolonged magmatic residence, or magmatic recycling. A total of four younger grains $(\mathrm{z} 41, \mathrm{z} 42, \mathrm{z} 44, \mathrm{z} 45)$ that overlapped were considered for the final weighted mean age of the ash bed of $140.338 \pm 0.083 / 0 / 091 / 0.18 \mathrm{Ma}$, MSWD $=1.1$

\subsection{Ash bed LL13}

Ash bed LL13 is located in stratigraphic height $2 \mathrm{~m}$ in the Las Loicas section. Zircon yield very low ca. > 10 grains. Zircons crystals ranged from $40-80 \mu \mathrm{m}$ in size. Grains were mainly prismatic with aspect ratio of 1:8. Radiogenic $\mathrm{Pb}$ ranged from 7 to $8 \mathrm{pg}$ (TS.1). The only three three grains that overlapped and reasonably respecting stratigraphic superposition were selected to represent the age of the sample, with 7 grains being discarded for being too (> 450 Ma) and having no geological meaning to the age of the sample. Grains that are much older than the youngest population are hard to interpret if they are inherited grains or detrital, therefore they were discarded. A total of 3 younger grains $(\mathrm{z} 9, \mathrm{z33}, \mathrm{z} 34)$ that overlapped were considered for the final weighted mean age of the ash bed of $142.039 \pm 0.058 / 0.069 / 0.17 \mathrm{Ma}$, MSWD 3.5.

\subsection{Ash bed LY5}

Ash bed LY5 is located $1.5 \mathrm{~m}$ below the contact of the Vaca Muerta Fm. and the Tordillo Fm (FS. 1B). Zircon yield was high ca. > 150 grains. Zircons crystals ranged from 20-100 $\mu \mathrm{m}$ in size. Grains were mainly prismatic with aspect ratio of 1:8 and rounded grains with aspect ratio of 1:3 were also very common. The ash bed is located in the Tordillo Fm, a silisiclastic unit. This sample had a significant amount of inherited and or detrital grains in the sample distribution. In a first batch of dated grains by CA-ID-TIMS the age distribution had a very large interval 180-450 Ma. Therefore, to optimize time we scanned the distribution of ages of the sample via LA-ICP-MS U-Pb geochronology. Grains were imaged via Cathodoluminescence and 250 grains were analyzed. Subsequently, the twenty youngest grains (135-145 Ma), based on Concordia ages, were selected to be analyzed via CA-IDTIMS to obtain a reliable depositional age for the ash bed. A total of seven grains were selected to represent the age distribution of the sample, with thirteen grains being discarded 
for being too old (> 150 Ma) and considered either inherited grains or prolonged magmatic residence or magmatic recycling. A total of four younger grains $(z 10, z 20, z 38, z 44)$ that overlapped were considered for the final weighted mean age of the ash bed of $147.112 \pm$ 0.078/0/088/0.18 Ma, MSWD = 0.81. Radiogenic Pb ranged from 1 to $6 \mathrm{pg}$ (TS.1).

\subsection{Ash bed MZT-81}

Ash bed MZT-81 is located in stratigraphic height ca. $22.5 \mathrm{~m}$ in the Mazatepec section. Zircon yield high ca. > 100 grains. Zircons crystals ranged from 40-80 $\mu \mathrm{m}$ in size. Grains were mainly prismatic with aspect ratio of 1:8. Radiogenic Pb ranged from 1 to 6 pg (TS.1), notably lower than other the other samples. A total of eight grains were selected to represent the age distribution of the sample, with 4 grains being discarded for being too old (> 150 $\mathrm{Ma}$ ) and considered either inherited grains or prolonged magmatic residence, or magmatic recycling. A total of four younger grains $(\mathrm{z} 4, \mathrm{z6}, \mathrm{z8}, \mathrm{z10})$ that overlapped were considered for the final weighted mean age of the ash bed of $140.512 \pm 0.031 / 0 / 048 / 0.16 \mathrm{Ma}, \mathrm{MSWD}=0.56$

\section{Age-depth modelling - Bchron Code}

library(Bchron)

mydata2 $=$ read.table(file $=' \backslash \backslash U$ sers $\backslash \backslash$ fortesd0\\Documents $\backslash \backslash R \|$ win-

library \3.4\Bchron $\mid$ OregonPliens.txt', header=TRUE)

GlenOut $=$ Bchronology $($ ages $=$ mydata 2 ages,

age $S d s=$ mydata $2 \$ a g e S d s$,

calCurves $=$ mydata 2 calCurves,

positions $=$ mydata 2 position,

positionThicknesses $=$ mydata2 $\$$ thickness,

ids=mydata 2 id

predictPositions $=\operatorname{seq}(0,8400$, by $=10)$, iterations $=10000)$

plot(GlenOut,main="NeuquenBchron",xlab='Age (Ma)',ylab='Depth (cm)',las=1)

summary(GlenOut)

summary(GlenOut, type='convergence')

summary(GlenOut, type='outliers')

Output <- cbind(apply(GlenOut\$thetaPredict, 2, quantile, probs $=\mathrm{c}(.0025))$,

apply(GlenOut\$thetaPredict, 2, quantile, probs $=\mathrm{c}(.5))$,

apply $($ GlenOut\$thetaPredict, 2, quantile, probs $=\mathrm{c}(.975)))$

write. $\operatorname{csv}($ Output, file $=$ 'whatever.csv', quote $=$ FALSE, row.names $=$ FALSE $)$

acc_rate $=$ summary $($ GlenOut, type $=$ 'acc_rate' $)$ 
plot(acc_rate[,'age_grid'], acc_rate[,'50\%'], type='l', ylab = 'cm per year', xlab = 'Age (k cal years BP)', ylim = range $($ acc_rate[,-1]))

lines(acc_rate[,'age_grid'], acc_rate[,'2.5\%'], lty='dotted')

lines(acc_rate[,'age_grid'], acc_rate[,'97.5\%'], lty='dotted')

sed_rate = summary $($ GlenOut, type $=$ 'sed_rate', useExisting $=$ FALSE)

plot(sed_rate[,'position_grid'], sed_rate[,'50\%'], type='1', ylab = 'Years per cm', xlab = 'Depth $(\mathrm{cm})^{\prime}$, ylim $=$ range $($ sed_rate[,-1]))

lines(sed_rate[,'position_grid'], sed_rate[,'2.5\%'], lty='dotted')

lines(sed_rate[,'position_grid'], sed_rate[,'97.5\%'], lty='dotted')

write.csv $($ sed_rate, file $=$ 'NeuquenBchron_sed_rates.csv', quote=FALSE, row.names $=$ FALSE)

write.csv $($ GlenOut, file $=$ 'NeuquenBchron_sed_rates.csv', quote=FALSE, row.names $=$ FALSE) 
7. Supplementary Figure 1 - Fig. S1

\begin{tabular}{|c|c|c|c|c|c|c|c|c|c|c|c|c|c|c|c|c|c|c|c|c|}
\hline & 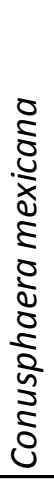 & 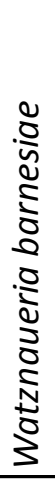 & 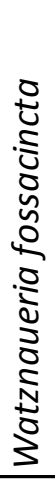 & 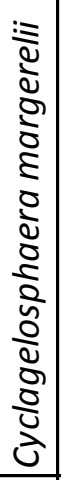 & 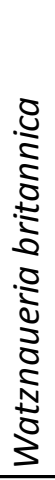 & 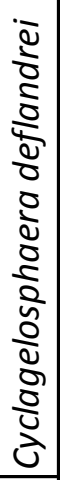 & 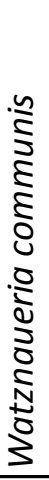 & 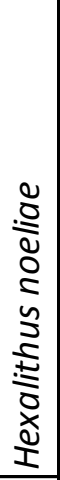 & 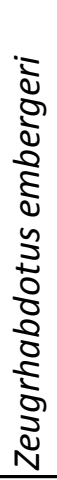 & 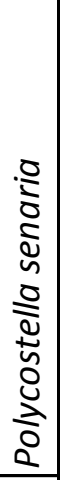 & 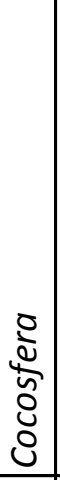 & 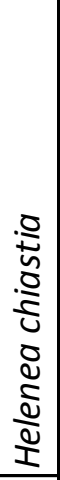 & 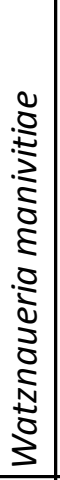 & 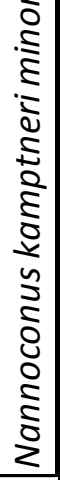 & $\begin{array}{l}0 \\
n \\
n \\
\vdots \\
5 \\
0 \\
0 \\
0 \\
\vdots \\
z\end{array}$ & 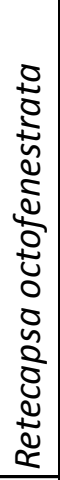 & 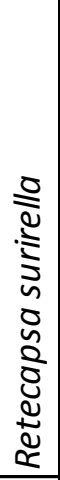 & 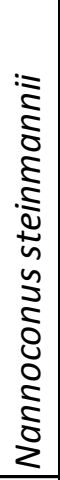 & 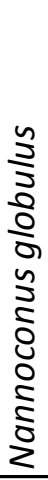 & 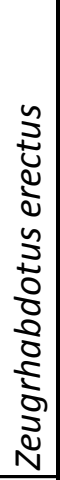 \\
\hline MZT-92 & & $x$ & & $x$ & & & & & & & & & & & & & & $x$ & & \\
\hline MZT-87 & & $x$ & $x$ & $x$ & $x$ & & & & & & & & $X$ & $x$ & $X$ & & $x$ & $x$ & $x$ & $X$ \\
\hline MZT-84 & & $x$ & & & & & & & & & & & & & & $x$ & & & & \\
\hline MZT-69 & & $x$ & & $x$ & & & & & & $x$ & & & & & & & & & & \\
\hline MZT-68 & & & & $x$ & $x$ & & & & $x$ & $x$ & & & & & $x$ & & & & & \\
\hline MZT-65 & & $x$ & $x$ & & & & & $x$ & & $x$ & & $x$ & $x$ & $x$ & & & & & & \\
\hline MZT-58 & & $x$ & $x$ & $x$ & & & & & $x$ & & $x$ & & & & & & & & & \\
\hline MZT-55 & & $x$ & & $X$ & & & & & & $X$ & & & & & & & & & & \\
\hline MZT-51 & & $x$ & $x$ & & & & & & & & & & & & & & & & & \\
\hline MZT-47 & & $x$ & & $x$ & $x$ & $x$ & & & & & & & & & & & & & & \\
\hline MZT-45 & $x$ & $x$ & $x$ & & & & & & $x$ & & & & & & & & & & & \\
\hline MZT-30 & $x$ & $x$ & & $x$ & $x$ & $x$ & $x$ & $x$ & & & & & & & & & & & & \\
\hline MZT-25 & & $x$ & & & & & & & & & & & & & & & & & & \\
\hline MZT-16 & & $x$ & $x$ & & & & & & & & & & & & & & & & & \\
\hline MZT-15 & $x$ & $x$ & $x$ & $x$ & & & & & & & & & & & & & & & & \\
\hline MZT-12 & $x$ & $x$ & $x$ & $x$ & & & & & & & & & & & & & & & & \\
\hline MZT-6 & $x$ & $x$ & $x$ & $x$ & $x$ & & & & & & & & & & & & & & & \\
\hline
\end{tabular}

Supplementary Figure 1. Stratigraphic distribution of calcareous nannofossils of Mazatepec section, Mexico. 
8. Supplementary Figure 2 - Fig. S2 - Field Figures

8 

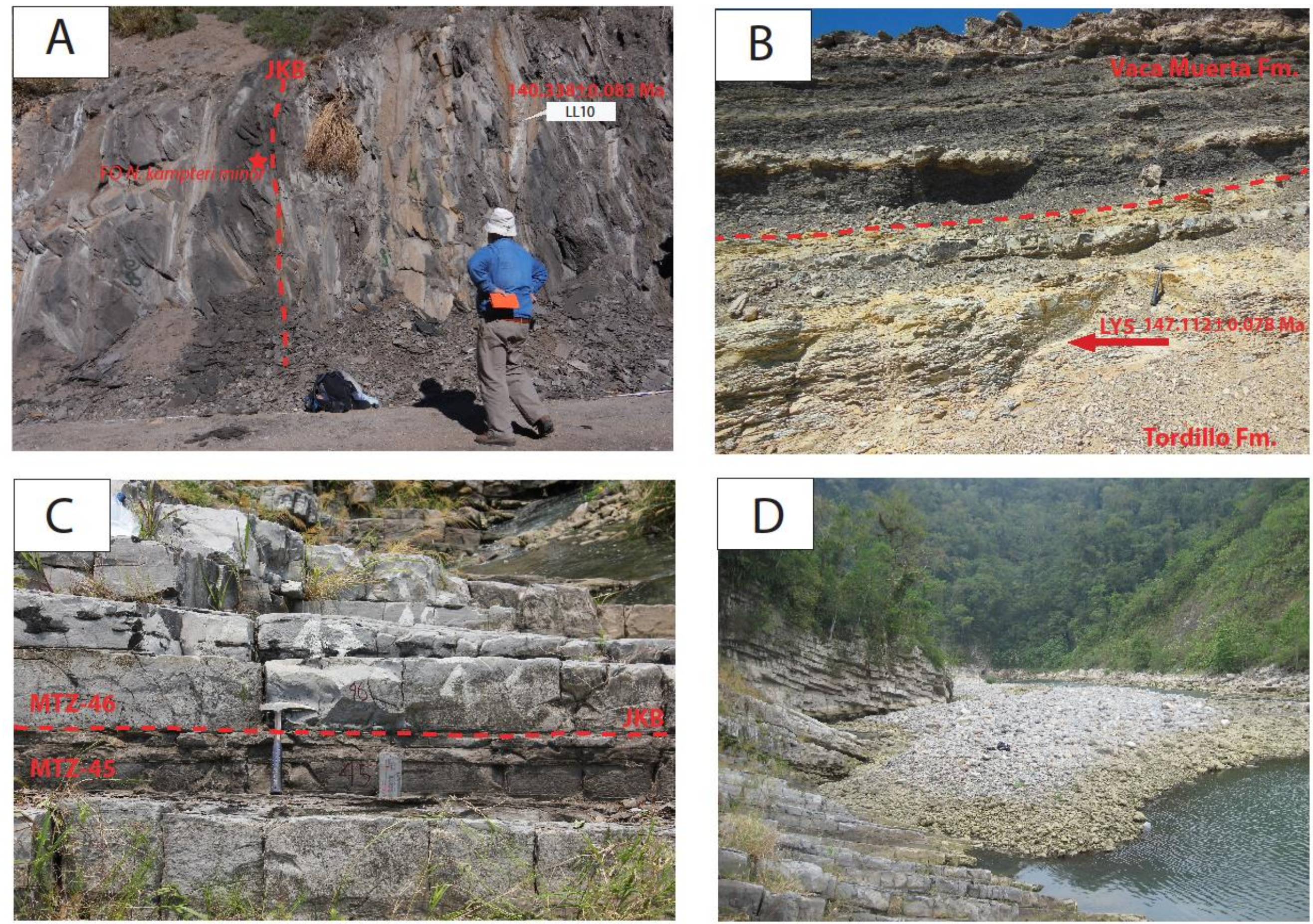
Supplementary Figure 2 - Field photos. A) Field figure from the Las Loicas section. Location of ash bed LL10 and the location of the JKB in the section. B) Field figure of the lower part of the La Yesera section where the contact between the Vaca Muerta and the Tordillo formations, and the location of ash bed LY5. C) location of the JKB in the Mazatepec section in Mexico, see bed MTZ-46 and MTY-45 (see Lopey-Matinez et al. 2013) D) Outcrop view of the Mazatepec section. 


\section{Data tables}

\subsection{U-Pb geochronology data table TS.1}

\begin{tabular}{|c|c|c|c|c|c|c|c|c|c|c|c|c|}
\hline \multirow{2}{*}{ Fraction } & & \multicolumn{4}{|l|}{ Dates (Ma) } & \multicolumn{7}{|c|}{ Composition } \\
\hline & & $\begin{array}{l}206 \mathrm{~Pb} / \\
238 \mathrm{U} \\
<\mathrm{Th}>\mathbf{a}\end{array}$ & $\begin{array}{l} \pm 2 \sigma \\
\text { abs }\end{array}$ & $\begin{array}{l}207 \mathrm{~Pb} / \\
235 \mathrm{U} \mathbf{b}\end{array}$ & $\begin{array}{l} \pm 2 \sigma \\
\text { abs }\end{array}$ & $\begin{array}{l}\text { Th/ } \\
\text { U C }\end{array}$ & $\begin{array}{l}\mathrm{Pb}^{\star} \\
(\mathrm{pg}) \mathbf{d}\end{array}$ & $\begin{array}{l}\mathrm{Pbc} \\
(\mathrm{pg}) \mathbf{e}\end{array}$ & $\begin{array}{l}206 \mathrm{~Pb} / \\
238 \mathrm{U} \mathbf{f}\end{array}$ & $\pm 2 \sigma \%$ & $\begin{array}{l}207 \mathrm{~Pb} / \\
235 \mathrm{f} f\end{array}$ & $\pm 2 \sigma \%$ \\
\hline \multicolumn{13}{|l|}{ LL3 } \\
\hline & $z 1$ & 139.43 & 0.11 & 138.0 & 1.1 & 0.97 & 10.4 & 0.75 & 0.021852 & 0.080 & 0.1456 & 0.88 \\
\hline & $z 2$ & 139.36 & 0.11 & 138.75 & 0.76 & 0.88 & 9.76 & 0.43 & 0.021842 & 0.079 & 0.14642 & 0.59 \\
\hline & z11 & 139.47 & 0.12 & 138.7 & 1.3 & 0.80 & 3.37 & 0.27 & 0.021858 & 0.088 & 0.1464 & 0.98 \\
\hline & $z 21$ & 139.45 & 0.11 & 139.8 & 1.1 & 0.97 & 7.21 & 0.48 & 0.021856 & 0.082 & 0.1476 & 0.84 \\
\hline & z22 & 139.44 & 0.12 & 139.2 & 1.2 & 0.79 & 4.10 & 0.22 & 0.021853 & 0.086 & 0.1469 & 0.93 \\
\hline & z23 & 139.16 & 0.14 & 136.4 & 1.5 & 0.90 & 4.68 & 0.42 & 0.021809 & 0.10 & 0.1437 & 1.2 \\
\hline & $z 25$ & 139.244 & 0.067 & 136.71 & 0.70 & 0.75 & 5.08 & 0.21 & 0.021822 & 0.048 & 0.14413 & 0.55 \\
\hline & z26 & 139.27 & 0.10 & 139.45 & 0.77 & 0.79 & 7.78 & 0.37 & 0.021826 & 0.075 & 0.14721 & 0.59 \\
\hline & z32 & 139.23 & 0.13 & 139.2 & 1.1 & 0.90 & 6.41 & 0.37 & 0.021820 & 0.093 & 0.1469 & 0.88 \\
\hline \multicolumn{13}{|l|}{ LL9 } \\
\hline & $z 2$ & 139.98 & 0.11 & 144.6 & 5.2 & 0.73 & 8.68 & 1.02 & 0.021938 & 0.077 & 0.1531 & 3.9 \\
\hline & z5 & 140.191 & 0.063 & 141.2 & 1.2 & 0.47 & 14.0 & 0.40 & 0.0219707 & 0.045 & 0.1492 & 0.90 \\
\hline & z7 & 140.19 & 0.14 & 141.7 & 2.3 & 0.53 & 8.56 & 0.46 & 0.021971 & 0.097 & 0.1498 & 1.8 \\
\hline & z12 & 139.99 & 0.16 & 150 & 11 & 0.37 & 1.94 & 0.55 & 0.021938 & 0.11 & 0.159 & 8.2 \\
\hline & z33 & 140.456 & 0.071 & 141.3 & 1.0 & 0.47 & 10.3 & 0.24 & 0.022013 & 0.051 & 0.1493 & 0.78 \\
\hline & z34 & 140.814 & 0.078 & 141.5 & 1.7 & 0.78 & 5.62 & 0.21 & 0.022071 & 0.056 & 0.1495 & 1.3 \\
\hline & z51 & 139.87 & 0.22 & 153 & 15 & 0.37 & 2.54 & 0.96 & 0.021919 & 0.16 & 0.162 & 11 \\
\hline & z52 & 140.67 & 0.11 & 143.6 & 5.0 & 0.81 & 3.13 & 0.34 & 0.022048 & 0.078 & 0.1519 & 3.7 \\
\hline & $z 53$ & 140.18 & 0.14 & 140.7 & 2.5 & 0.65 & 5.33 & 0.29 & 0.021970 & 0.10 & 0.1486 & 1.9 \\
\hline & z54 & 140.35 & 0.11 & 142.4 & 3.3 & 0.71 & 3.72 & 0.27 & 0.021997 & 0.080 & 0.1506 & 2.5 \\
\hline & z55 & 139.945 & 0.097 & 141.5 & 2.5 & 0.50 & 6.57 & 0.39 & 0.021932 & 0.070 & 0.1495 & 1.9 \\
\hline \multicolumn{13}{|l|}{ LL10 } \\
\hline & $z 11$ & 140.51 & 0.13 & 140.1 & 1.4 & 0.82 & 4.08 & 0.37 & 0.022023 & 0.096 & 0.1479 & 1.1 \\
\hline & z12 & 141.20 & 0.35 & 140.2 & 3.8 & 0.93 & 1.01 & 0.24 & 0.022134 & 0.25 & 0.1481 & 2.9 \\
\hline & z13 & 140.61 & 0.26 & 139.6 & 3.0 & 0.93 & 2.57 & 0.49 & 0.022039 & 0.18 & 0.1474 & 2.3 \\
\hline
\end{tabular}




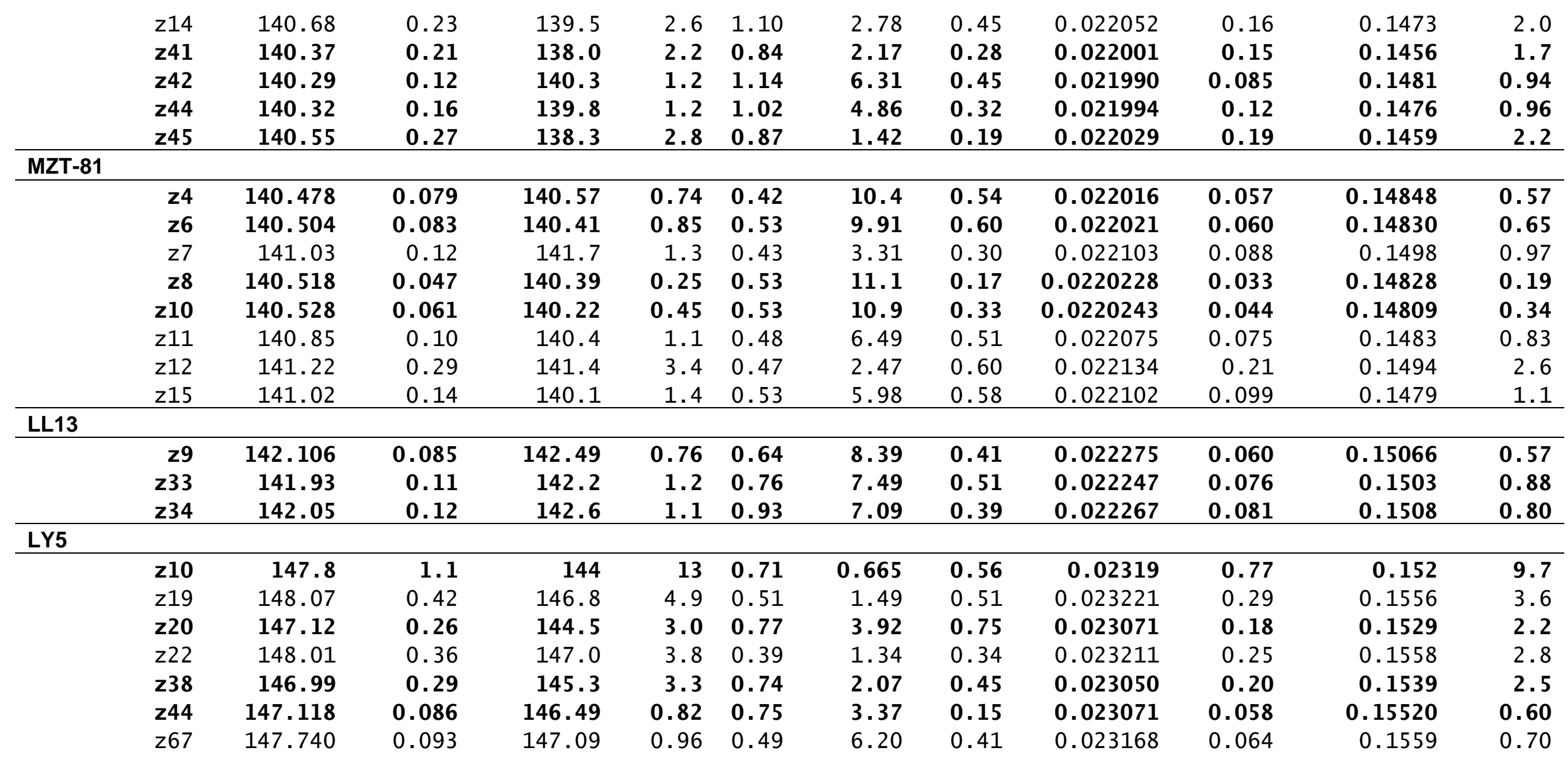



a) Corrected for initial $\mathrm{Th} / \mathrm{U}$ disequilibrium using the radiogenic $208 \mathrm{~Pb}$ and $\mathrm{Th} / \mathrm{U}$ (magma) $=3.5$
b) Isotopic dates calculated using $238=1.55125 \mathrm{E}-10$ (Jaffey et al. 1971) and 235=9.8485E-10 (Jaffey et al. 1971)
c) Th contents calculated from radiogenic $208 \mathrm{~Pb}$ and $239^{\mathrm{Th}}$-corrected $206 \mathrm{~Pb} / 207 \mathrm{~Pb}$ date of the sample, assuming concordance between $\mathrm{U}-\mathrm{Pb}$ and $\mathrm{Th}-\mathrm{Pb}$ systems
d) Total mass of radiogenic $\mathrm{Pb}$
e) Total mass of common $\mathrm{Pb}$
f) Measured ratios correct for fractionation, tracer and blank.

\subsection{Age-depth model data table TS.2}

\begin{tabular}{|c|c|c|c|c|c|}
\hline $\begin{array}{c}\text { Stratigraphic } \\
\text { Height }(\mathrm{m})\end{array}$ & Age (Ma) & $\begin{array}{l}\text { Std Err (2 } \\
\text { S.D) (Ma) }\end{array}$ & $\begin{array}{c}\text { Stratigraphic } \\
\text { Height }(m)\end{array}$ & Age (Ma) & $\begin{array}{l}\text { Std Err (2 } \\
\text { S.D) (Ma) }\end{array}$ \\
\hline 54 & 139.24 & 0.05 & 15 & 141.31 & 0.56 \\
\hline 53 & 139.30 & 0.15 & 14 & 141.37 & 0.56 \\
\hline 52 & 139.35 & 0.20 & 13 & 141.43 & 0.52 \\
\hline 51 & 139.41 & 0.22 & 12 & 141.50 & 0.51 \\
\hline 50 & 139.46 & 0.23 & 11 & 141.56 & 0.50 \\
\hline 49 & 139.51 & 0.23 & 10 & 141.62 & 0.49 \\
\hline 48 & 139.57 & 0.24 & 9 & 141.68 & 0.47 \\
\hline 47 & 139.62 & 0.23 & 8 & 141.74 & 0.44 \\
\hline 46 & 139.68 & 0.24 & 7 & 141.80 & 0.40 \\
\hline 45 & 139.73 & 0.23 & 6 & 141.86 & 0.36 \\
\hline 44 & 139.79 & 0.22 & 5 & 141.92 & 0.33 \\
\hline 43 & 139.84 & 0.21 & 4 & 141.97 & 0.23 \\
\hline 42 & 139.90 & 0.17 & 3 & 142.04 & 0.06 \\
\hline 41 & 139.96 & 0.07 & 2 & 142.10 & 0.32 \\
\hline 40 & 140.00 & 0.10 & 1 & 142.15 & 0.42 \\
\hline 39 & 140.03 & 0.12 & & & \\
\hline 38 & 140.07 & 0.12 & & & \\
\hline 37 & 140.11 & 0.13 & & & \\
\hline 36 & 140.15 & 0.13 & & & \\
\hline 35 & 140.18 & 0.13 & & & \\
\hline 34 & 140.22 & 0.13 & & & \\
\hline 33 & 140.27 & 0.12 & & & \\
\hline 32 & 140.31 & 0.11 & & & \\
\hline 31 & 140.35 & 0.08 & & & \\
\hline 30 & 140.42 & 0.23 & & & \\
\hline 29 & 140.48 & 0.30 & & & \\
\hline 28 & 140.54 & 0.37 & & & \\
\hline
\end{tabular}




$\begin{array}{lll}27 & 140.60 & 0.41 \\ 26 & 140.66 & 0.43 \\ 25 & 140.72 & 0.46 \\ 24 & 140.78 & 0.50 \\ 23 & 140.84 & 0.50 \\ 22 & 140.90 & 0.52 \\ 21 & 140.96 & 0.53 \\ 20 & 141.02 & 0.55 \\ 19 & 141.08 & 0.56 \\ 18 & 141.14 & 0.55 \\ 17 & 141.20 & 0.56 \\ 16 & 141.26 & 0.56\end{array}$

\section{References}

Blackburn, T. J., Olsen, P. E., Bowring, S. A., McLean, N. M., Kent, D. V., Puffer, J., McHone, J. G., Rasbury, E. T. and Et-Touhami, M.: Zircon U-Pb geochronology links the end-Triassic extinction with the Central Atlantic Magmatic Province., Science, 340(6135), 941-5, doi:10.1126/science.1234204, 2013. Bowring, J. F., McLean, N. M. and Bowring, S. A.: Engineering cyber infrastructure for U-Pb geochronology: Tripoli and U-Pb-Redux, Geochemistry, Geophys. Geosystems, doi:10.1029/2010GC003479, 2012.

Chen, J. H. and Wasserburg, G. J.: A search for isotopic anomalies in uranium, Geophys. Res. Lett., 7(4), 275-278, doi:10.1029/GL007i004p00275, 1980.

Jaffey, A. H., Flynn, K. F., Glendenin, L. E., Bentley, W. C. and Essling, A. M.:

Precision measurement of half-lives and specific activities of U235 and U238, Phys. Rev. C, 4(5), 1889-1906, doi:10.1103/PhysRevC.4.1889, 1971.

Mattinson, J. M.: Zircon U-Pb chemical abrasion (“CA-TIMS") method: Combined annealing and multi-step partial dissolution analysis for improved precision and accuracy of zircon ages, Chem. Geol., 220(1-2), 47-66, doi:10.1016/j.chemgeo.2005.03.011, 2005.

McLean, N. M., Bowring, J. F. and Bowring, S. A.: An algorithm for U-Pb isotope dilution data reduction and uncertainty propagation, Geochemistry, Geophys. Geosystems, 12(6), doi:10.1029/2010GC003478, 2011.

Parrish, R. R. and Krogh, T. E.: Synthesis and purification of $205 \mathrm{~Pb}$ for U-Pb geochronology, Chem. Geol., 66(1-2), 103-110, doi:10.1016/0168-9622(87)900339, 1987.

Parrish, R. R., Bowring, S. A., Condon, D. J., Schoene, B., Crowley, J. L. and Ramezani, J.: EARTHTIME U-PB tracer for community use, Geochim. Cosmochim. Acta, 70(18), A473, doi:10.1016/j.gca.2006.06.1408, 2006. 
